\title{
Influence of the Working Conditions of the Support Staff on their Work Performance in Secondary Schools in Rarieda Sub-County, Kenya
}

\author{
Ms. Ann Akinyi Opondo \\ St. Vincent Raliew Secondary, Box 22, Nyilima \\ akinyiopondo@yahoo.com \\ Dr. Jack Odongo Ajowi*
}

Jaramogi Oginga Odinga University of Science and Technology, Box 210 - 40601, Bondo

jackajowi@yahoo.com

Doi:10.5901/ajis.2015.v4n1p227

\section{Abstract}

Support staff plays a pivotal role in secondary schools by helping to reduce none teaching load on teachers. However, they do this under very difficult conditions such as low salaries and wages, work more than 8 hours a day, are required to work in undesignated areas and are not recognized in their work. Therefore, the purpose of the study was to establish the influence of the working conditions of the support staff on work performance in public secondary schools in Rarieda Sub-County. Objectives of the study were to: examine the working conditions of support staff; establish the influence of the work conditions on performance of support staff; determine challenges faced by support staff in their duties and find out how support staffs cope with challenges faced. A conceptual frame work was used to guide the study. The conceptual frame work proposes that if work conditions are favourable then work performance improves. The study population consisted of 180 support staff, 34 head teachers and 34 BOM chairpersons from 34 secondary schools. Saturated sampling technique was used to select 31 head teachers and 31 BOM chairpersons. Saturated sampling technique used to select 150 support staff. The instruments of data collection were questionnaires and interview schedules. The questionnaires were administered to the head teachers and support staff while the interviews were conducted to the support staff and Board of Management chairpersons. Content validity of the instruments was ascertained by experts from the School of Education, Jaramogi Oginga Odinga University of Science and Technology. A pilot study was carried out in 3 schools which were not part of the main study to establish the reliability of the instruments by using the outcome to remove the ambiguities, inconsistencies and weaknesses noted. Quantitative data from closed-ended questionnaire were analyzed using descriptive statistics such as frequency counts, percentages and means. Qualitative data from open-ended sections of the questionnaires and interviews were analyzed by organizing the content into themes and sub themes as they emerged, then tallied and presented through verbatim reporting. The study revealed that conditions of work influence work performance of support staff. The study also found that support staff in Rarieda Sub-County work under poor conditions. They experienced challenges such as inadequate working tools, low salary, inadequate housing and are overworked. In coping with the challenges faced, support staff carried tools from home, engaged in small scale businesses and odd jobs, commuted from their homes and others who are unable to cope persevered. The study recommended that: Ministry of Education should improve support staff working conditions by taking up full payment of support staff salaries, increasing support staff salaries, putting up houses for support staff, recruiting more support staff and increasing FSE funds to enable schools acquire enough working tools. The study may be useful to the policy makers in realizing how work conditions influence performance of support staff; head teachers to discover successful strategies of improving work conditions of support staff; and in providing baseline information for further research in conditions of work of support staff.

Keywords: Influence; Working conditions; Support Staff; Performance.

\section{Introduction}

Education is regarded as a prime mover for socio-economic development and accounts for as much as $20 \%$ of the Gross National Product of developing nations. This is based on the observation that education improves the productive value of human beings by imparting knowledge, skills, attitude and behavior traits referred to as human, social and cultural capital which are required in producing goods and services (Lazear, 2002 \& Higlis, 2008). In England and Wales, secondary school support staffs were less satisfied with their posts in general, their contracts and conditions of employment, working arrangements for their post, training and development they had received in their role, and training and development opportunities available to them (Deci, 2000). Nakpodia (2010) revealed in his study on human 
resources in schools in Nigeria that conditions of work impact positively on performance of support staff. In Uganda public service structure and conditions of employment have a direct bearing on the conduct of public servants for instance when wages are insufficient to support a family, it becomes more difficult to avoid moonlighting and speedy money acquired through corruption (Republic of Kenya, 2011).

The true wealth of any nation is its human resources, and the worth of any organization is its workforce (Republic of Kenya, 2006). The importance of staff in any educational system cannot be over-emphasized and for workers to perform their duties well, then working conditions should be favorable. Sagimo (2002) maintained that employees and managers have to work in harmony, better cooperation and understanding in order to increase their productivity. It is therefore worth noting that every teaching institution needs not only the teaching staff, but also a motivated support staff to assist in running other services at the school (Bakhda, 2004). Republic of Kenya (2006) report asserts that to ensure staff satisfaction and effective utilization of the available human resources for increased productivity, the working environment and conditions of service must be conducive and attractive. In Kenya a huge number of employees who are skilled and semi skilled end up securing employment in secondary schools. It is one of the largest employers of employees such as secretaries, bursars, librarians, cateresses and laboratory technicians (MOE, 2010). Majority of the support staff do not belong to any union hence serve at the goodwill of school administrators who determine their fate according to school enrolment and terms and conditions of employment of support staff (KUDHEIHA, 2010). These sentiments are supported by members of parliament who claimed that support staff are at the mercy of head teachers with no chance of career progression (Mureithi, 2011). Guidelines for the implementation of free secondary education maintains that the government's vote head of personal emolument meant for support staff is hardly ever enough to pay for salaries, National Hospital Insurance Fund, National Social Security Fund and Retirement Benefits (MOE, 2010).

Welch (2006) observed that money, recognition, training, worker qualification, attitude and experience are the basic tools required to motivate and retain top performance. Yet according to a report by Republic of Kenya (1999), poor terms and conditions of service lead to poor morale. This is supported by Olayo (2011) when he suggests that to maximize employees output; they need to be comfortable both at work and home so as to minimize stress and stressors. Republic of Kenya (2010) report says that every person has the right to fair labour practices including fair remuneration, reasonable working conditions, a right to form, join or participate in the activities and programmes of a trade union and a right to go on strike. Though motivation and job satisfaction of teachers has widely been studied and proposals made, a gap still exists regarding the influence of conditions of work on performance of support staff that play pivotal role in making schools achieve their objectives. In Rarieda District public secondary schools, $90 \%$ of the support staff work under difficult conditions including low wages, lack of recognition, delay in payment of salaries, lack of job description and working past official working hours (Rarieda Sub-County Education office Statistics, 2012).

Support staff makes a vital contribution to student's education and smooth running of schools. In Rarieda subcounty, support staff survives at the mercy of school management who determine their terms and conditions of employment. This has resulted in low wages that can hardly meet support staff needs as school managements do claim that the government's personal emolument vote meant for support staff salaries is hardly enough, support staff also suffer lack of job security, working more than the eight official hours; they are also assigned work beyond what is stipulated in their job descriptions. This is further complicated by the facts that, majority of them do not belong to trade unions since they are either casual workers or on contract. Most of the workers are faced with delayed salaries especially during the third term of the school calendar as the school management claims they had run short of funds. Support staff also suffers lack of medical cover, lack of working tools and protective gears when at work. In addition support staff also lack training opportunities, receive less sick leave than teachers although they are exposed to similar health risks at work, not sure of pay progression, not being paid during school holidays. As a result, support staff are no longer dedicated and committed to the job; they are expected to show virtues like honesty, humility, dedication and integrity at work place instead they are not dedicated and not committed to their jobs. This study was set to establish the influence of the working conditions of support staff on their work performance in public secondary schools in Rarieda Sub-County.

The purpose of this study was to establish the influence of the working conditions of the support staff on their work performance in public secondary schools in Rarieda Sub-County.

Specific objectives of the study were to:

i) Assess the working environment of the support staff in public secondary schools in Rarieda Sub-County.

ii) Establish the effects of the working conditions of the support staff on their performance in public secondary schools in Rarieda Sub-County.

iii) Determine the challenges faced by support staff in Rarieda Sub-County public secondary schools.

iv) Assess how support staff cope with the challenges they face in public Secondary Schools in Rarieda Sub- 
County.

\section{Research Methodology}

\subsection{Research Design}

The researcher employed the descriptive survey and ex post facto design. A descriptive survey design involved asking a large group of respondents questions about a particular issue (Mugenda, 1999). The information is obtained from a sample rather than entire population, if the population is too large. The design has an advantage because it is easy to apply research instruments such as questionnaires and interview schedules which also allow for the collection of data from large number of respondents in a relatively short period with minimum cost. Kerlinger (1975) states that ex post facto is a systematic, empirical inquiry in which the researcher does not have direct control of independent variables because their manifestations have already occurred. In this study, the conditions of work of support staff have already occurred by the time data was being collected. The advantage of ex post facto design is that the data cannot be manipulated by the researcher or the respondents (Borg \& Gall, 1983).

The study was carried out in Rarieda Sub-County in Siaya County, Kenya. The sub-county borders Siaya subcounty to the North, Bondo sub-county to the North West and Kisumu West Sub-County to the North East and Homa-bay Sub-County to the South. Rarieda Sub-County was curved off from Bondo sub-county. It is sparsely populated. The main economic activities are fishing, livestock keeping and peasant farming. The Sub-County has 34 secondary schools and 114 primary schools. According to the sub-county Statistics, Rarieda has one of the highest HIVIAIDS prevalence $25 \%$ and poverty index $70 \%$ (Rarieda Sub- County Development Plan, 2010). The sub-county lies between Latitude $0^{\circ}$ to $12^{\circ}$ south of the Equator and Longitude $34^{\circ}$ to $19^{\circ}$ east. (For a sketch map of study area, see Appendix E). This area was suitable for this study because support staffs in Rarieda Sub-County's public secondary schools were reluctantly playing their pivotal role in helping the schools to meet their objectives compared to their counterparts in Siaya and Gem Subcounties (Rarieda Sub County Education office Statistics, 2012). The study population was 34 BOM chairpersons, 34 head teachers and 180 support staff, serving in Rarieda Sub-County public secondary schools (Sub-County Education Office, 2012). The BOM chairpersons, head teachers and support staff are better placed to provide information on the degree of relationship that exists between the conditions of work of support staff and their performance.

Table 3.1. Study Population

\begin{tabular}{cc}
\hline Category of Respondents & No \\
\hline BOM Chairpersons & 34 \\
Head teachers & 34 \\
Support Staff & 180 \\
\hline
\end{tabular}

Source: Rarieda Sub-County Education Office (2012).

Saturated sampling technique was used to select 31 BOM chair persons, 31 head teachers and 150 support staff. This was because BOM chair persons and Head teachers are instrumental in ensuring good working conditions for the support staff in public secondary schools. The major instruments to be used for data collection in this study included questionnaire and interview schedule. Each questionnaire comprised of open-ended and closed-ended questions. Questionnaires were used for data collection because they enabled the researcher to gather information from a larger number of respondents within a limited time. Questionnaires also enabled the researcher to get responses that some respondents would feel shy to give in face- to- face interviews (Fraenkel \& Wallen, 2009). The interview schedules were administered to the head teachers and BOM chairpersons. Interviews helped to solicit more detailed information from the respondents as it gave the researcher opportunity to probe the respondents for more information.

According to Orodho (2003) Validity is the extent to which research instruments measure what they are intended to measure. To ensure validity, three experts from the School of Education of Jaramogi Oginga Odinga University of Science and Technology examined the instruments and advised on content validity. Improvements were then made on final copies of the instruments in light of their recommendations. Mugenda (1999) stressed that validity of research instruments should be determined by experts.

Orodho and Okombo (2002) define reliability of an instrument as the degree of consistency with which it measures whatever it is measuring. Therefore, to test reliability of the instruments, the instruments were piloted in three schools 
outside the sampled schools. Ambiguities, misunderstandings or other inadequacies noted in the responses from the pilot study were corrected in the final instruments.

\subsection{Methods of Data Analysis}

Data analysis was done as per the research objectives as shown below;

i. The working conditions of the support staff in secondary schools were analyzed for content by organizing the content into themes and sub themes as they emerge, then tallied and presented in quoted words and phrases.

ii. The effects of the working conditions of the support staff on their performance in secondary schools were analyzed by using descriptive statistics such as frequency counts, percentages and means

iii. The challenges faced by support staff in secondary schools were analyzed using narrative summary analysis which was invented by Carol Gilligan (1982). In this technique the researcher put data together, not in their raw form, but in re-ordered form to tell stories from the points of view of different participants.

iv. Assess how support staff cope with the challenges they face in Secondary Schools was analyzed by using descriptive statistics such as frequency counts, percentages and means.

\section{Results And Discussion}

\subsection{Working Environment of the Support Staff in Public Secondary Schools}

The first objective was to assess the working environment of the support staff in public secondary schools in Rarieda Sub-County. The research question responded to was: How is the working environment of the support staff in secondary schools in Rarieda Sub-County? The respondents were asked to rate the working conditions according their magnitude, their responses were as shown in Table 4.5.

Table 4.5. Conditions of Work for Support Staff in Secondary Schools as reported by Head teachers $(n=31)$, Support Staff $(n=150)$

\begin{tabular}{lcccc}
\hline \multirow{2}{*}{ Working Conditions of Support Staff } & Head Teachers & \multicolumn{3}{c}{ Support Staff } \\
& $\mathbf{f}$ & $\%$ & $\mathbf{f}$ & $\%$ \\
\hline Lack of concern for individual needs by management & 28 & 90 & 150 & 100 \\
Lack of terms of service and job descriptions & 26 & 84 & 150 & 100 \\
Too much work allocation & 25 & 81 & 135 & 90 \\
Poor relations among workers & 20 & 65 & 130 & 87 \\
Non membership of trade unions & 18 & 58 & 126 & 84 \\
Lack of staff development & 15 & 48 & 120 & 80 \\
Lack of team work & 12 & 39 & 100 & 67 \\
Lack of commuter allowances & 12 & 39 & 97 & 64 \\
and inadequate house allowances & 10 & 32 & 89 & 59 \\
Threats from head teachers & & & & \\
\hline
\end{tabular}

Table 4.5 shows varied responses from the support staff and head teachers concerning the conditions of work that prevails in secondary schools. Lack of concern for individual needs by management was established as major working condition affecting work performance of support staff by most (90\%) head teachers and all (100\%) support staff. Most support staff lack terms of service as reported by most (84\%) head teachers and all (100\%) support staff. Too much work allocation was also established from (81\%) head teachers and (90\%) support staff. 


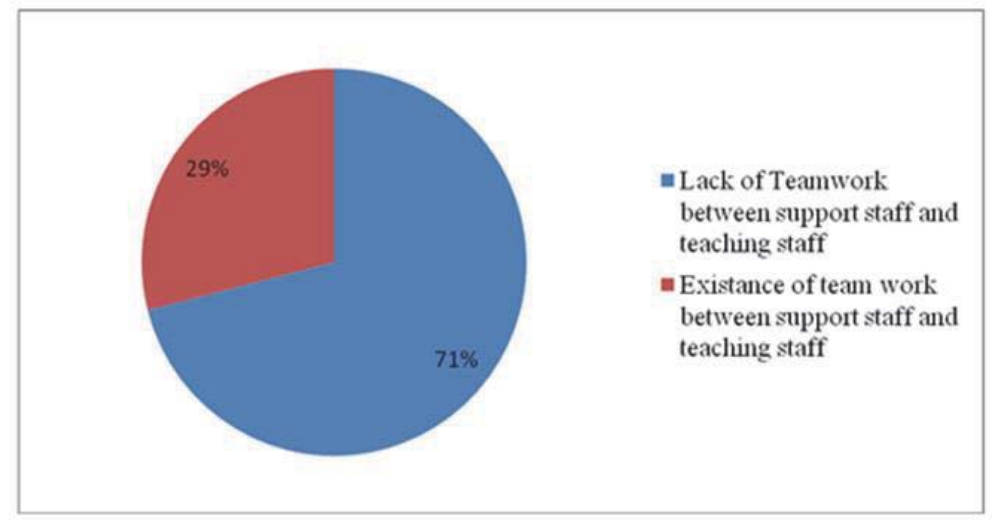

Figure 4.2: Support Staff Response on Teamwork among workers in school $(n=150)$

The study further established that there were poor relations among workers in secondary schools from some (65\%) head teachers and most (87\%) support staff. Most support staff were not members of trade unions as established from (58\%) head teachers and most (84\%) support staff. Lack of staff development was also established from (48\%) head teachers and some (80\%) support staff. Lack of team work was established as not of high magnitude among head teachers as only (39\%) mentioned its existence in schools but was vastly noted by (67\%) support staff. Equally lack of commuter allowances and inadequate house allowances was down played by head teachers as only (39\%) mention its existence in their schools, but well mentioned by (64\%) support staff. The study also established that there were threats from the head teachers to support staff as mentioned by some (59\%) support staff.

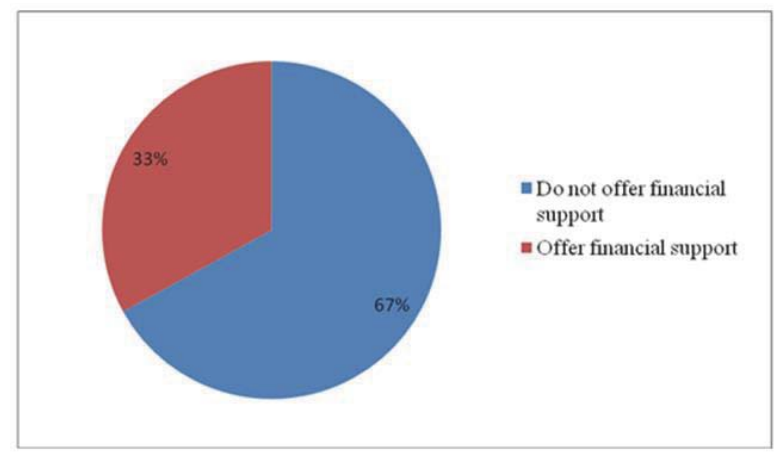

Figure 4.3: Principal's Response on the Financial Support Staff $(n=31)$

The study further established during interviews that most head teachers were not bothered about the welfare of the support staff under them. The head teachers who participated in the study maintained that some of the support staff were not genuine with the cases they were presenting and when the head teachers realized that, they developed laxity in tackling personal issues brought by the support staff. Some (67\%) principals mentioned how they had been cheated by support staff so as to get money from the school. This they said made them to develop an indifferent attitude towards the problems of support staff.

The support staff on the other hand during interviews maintained that head teachers were inhuman and were never having them at heart yet they were the most important part of the schools engine. To this attitude, the support staff maintained that the principals were forgetting that when people are recognized publicly for their contributions and achievements, it stimulates other workers to be more willing to work at the same job because they would also want to be recognized (Deci, 2001). Some (75\%) support staff noted various occasions when they had pressing issues but were denied permission from their places of work to attend to those problems. Equally other (89\%) support staff mentioned how they were denied financial support by the head teachers when they were in dire need. The principals were therefore forgetting the importance of trust as the most vital element in the development and maintenance of productive work environment. Trust do stimulates security and confidence as it is the prerequisite to innovation and creativity (Thompson, 
2002).

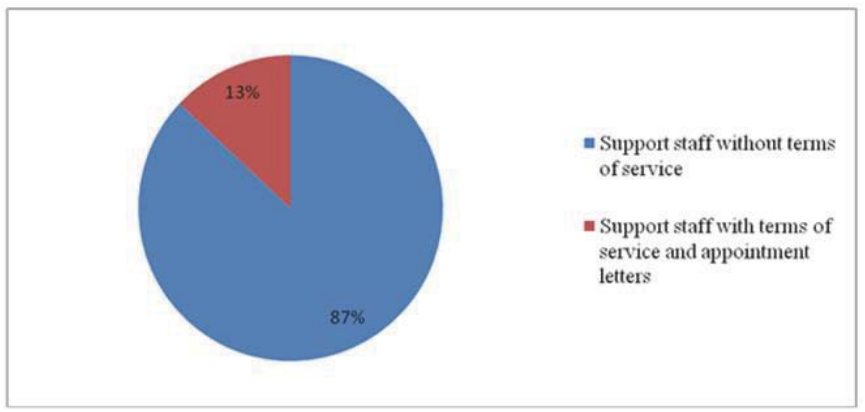

Figure 4.4: Support Staffs' response on their Terms of Service $(n=150)$

The study also established during interviews that most of the support staff in secondary schools was lacking terms of service and that majority was working as casual workers or on contract without letters affirming them to such positions. According to all (100\%) head teachers, they were engaging most support staff on casual basis terms because the government money through free secondary education was limiting the number of support staff to be employed yet there was need for manpower. They further reiterated that they were using Parents Teachers Association Development Funds to engage some support staff. Most $(98 \%)$ head teachers noted that they intentionally avoided giving most support staff terms of service so as to make them accept to do any duty assigned to them by the school administration.

Most (87\%) Support confirmed that they were not having terms of service or even job description as they were majorly being assigned duties on daily basis and were constantly being moved from one job area to another. These support staff further expressed their disappointment that they were always kept in the dark of where they will be transferred to next. Some (45\%) support staff were semi literate and could not see the importance of being given job description so long as they were on employment the other issues were not relevant. Some (76\%) support staff were of the opinion that they were neglected by trade unions and the government and left at the mercy of the head teachers.

Too much work allocation to the support staff was also established during interviews with head teachers. Most (97\%) agreed that they were giving too much work to the support staff. They were however quick to explain that this was due manpower shortage in schools. Some $(89 \%)$ head teachers also noted that most of their support staffs were on contract and were to be made use of to the maximum because it would not be wise to employ other people to work for them. Some (79\%) head teachers also noted that most of the people they were employing were not complaining of too much work as such they were not aware that they were giving them a lot of work.

Most (94\%) support staff maintained that they were being made a jack of all trade but master of none. As such they could not perform their duties diligently. One support staff who was employed as a watch man in secondary school explained how he was being overworked at night when he is a watch man at the gate at the same time was expected to cook overnight. Another grounds man claimed that he was expected to be cleaning the compound at the same time being school farm attendant thus feeding cows, milking and taking full control of chicken.

The study further established from the support staff that head teachers were not taking any action whenever they requested that new workers be added to ease their much work. Some (77\%) noted that they were suffering from certain diseases due to much work they were constantly engaged in. Another (23\%) support staff maintained that they did not have time for leisure activities because they were working from morning to evening and daily without taking weekends into consideration.

Some (84\%) head teachers agreed that they were witnessing poor relations among the workers. They further explained that teachers and support staff were not in good terms and even among support staff themselves. Other (67\%) head teachers explained how they had been struggling to ensure unity among the workers within their schools.

All (100\%) support staff agreed that they had differences among themselves and this was affecting smooth working environment. They instead blamed their head teachers for the scenario in their schools as they claim that some of the causes were because of lack of job description. Some (57\%) also blamed the administration for causing poor relations as they were using divide and rule tactics. These support staff further blamed the head teachers in their schools for siding with other group of workers against another group. Some (68\%) support staffs were blaming poor relations in schools for lack of self discipline among the workers which constantly leads to conflict among the workers.

Most (89\%) head teachers agreed that all their support staff were not members of trade unions. This they noted was due to many support staff being employed either on casual terms or on contract. The principals also blamed the 
support staff and trade unions for being reluctant to register members from schools. The support staffs were also not expecting school administrations to force them to register with their trade union (KUDHEIHA) which is their advocate against the employer.

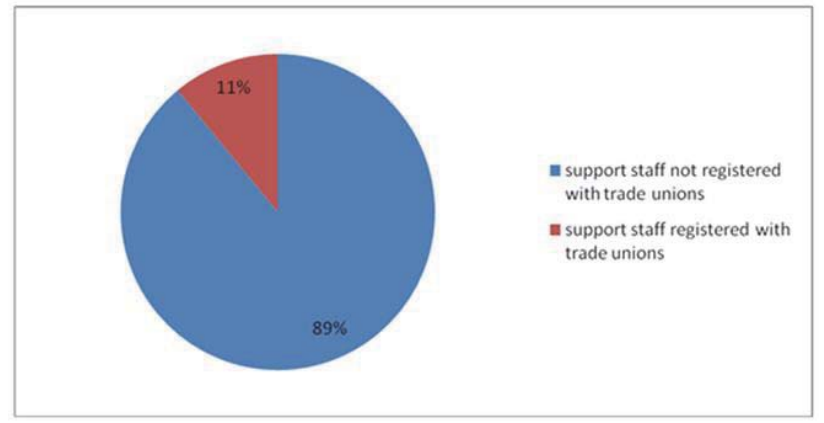

Figure 4.5: Principal's Response on the Support Staff membership with Trade Unions ( $n=31)$

On their part, all (100\%) support staff concurred with head teachers that they were not registered members of their trade union. This they blamed on the laxity from their trade union offices which had not realized that they were having members in secondary schools. Most (74\%) support staff blamed their counterparts who were ignorant and illiterate hence were not aware of the existence of trade union and what it stands for. The support staff finally blamed the head teachers whom they claim do not fully induct their new employees on the existence and importance of trade unions. All (100\%) support staff noted that working conditions were not favourable without trade unions as they had nowhere to turn to when facing high handedness from the school administration. This they noted was leading to high turnover rate of support staff in schools.

All $(100 \%)$ head teachers revealed that they were occasionally taking their support staffs for workshops to enable them improve new skills in their work as Bakhda (2004) observed that in-service training refreshes the skills of professionals by updating them on new trends in the profession. Some (87\%) head teachers however noted that most support staff does evade workshops even after being sponsored by their schools. The head teachers further indicated that in some areas like grounds men, they were organizing internal workshops so as to inform them of what they were expected to do. The principals equally recognized that workshops at schools aims at enhancing ideas, skills and attitudes that are needed by the employees for staff development (Republic of Kenya, 2011).

The study also established from all (100\%) support staff that staff development was lacking in secondary schools and that the head teachers were not willing to sponsor somebody for well organized workshops or for further training, The head teachers were forgetting that the main purpose of training is to raise competence and performance standards at their institutions (Republic of Kenya, 2011). They also noted that they were hardly getting internal promotions as such all were stagnant. Some $(79 \%)$ support staff noted that in their schools staff development was in practice as their head teachers were constantly talking of lack of funds to sponsor people for further training. The head teachers were forgetting that support staff needs opportunities for training and career development to enable them to progress and further contribute to school improvement (Briar, 2010).

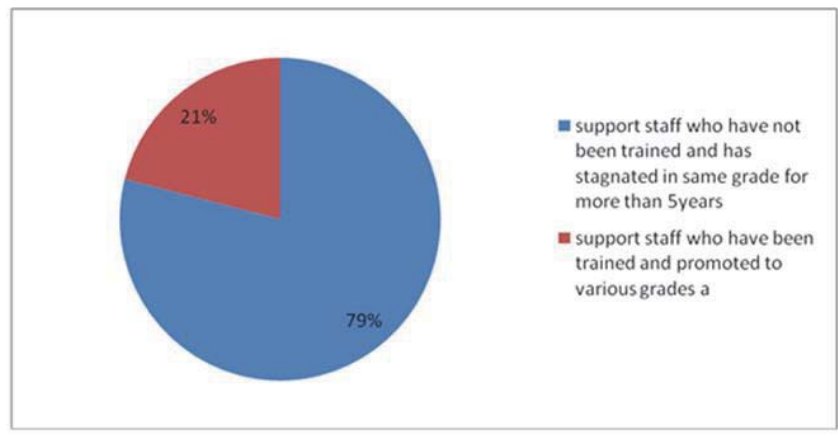

Figure 4.6: Support Staff Response on the Staff Development $(n=150)$ 
Lack of team work among support staff was also established by the study to be in existence among the workers in secondary schools. All (100\%) head teachers noted that most of them were from the surrounding communities and were carrying village differences to their workplace. The head teachers also maintained that most of the support staff were with shelter and transport. Some (82\%) noted that their morale was low as they were denied their rights while head teachers and teachers were getting their allowances from the government no matter where they were staying. The support staff noted that with the absence of commuter allowances they ended up feeling tired after walking or riding a bicycle for longer distance. The head teachers in this case had not realized that motivation or lack of it is a vital component in provision of quality secondary education (Simatwa, 2010).

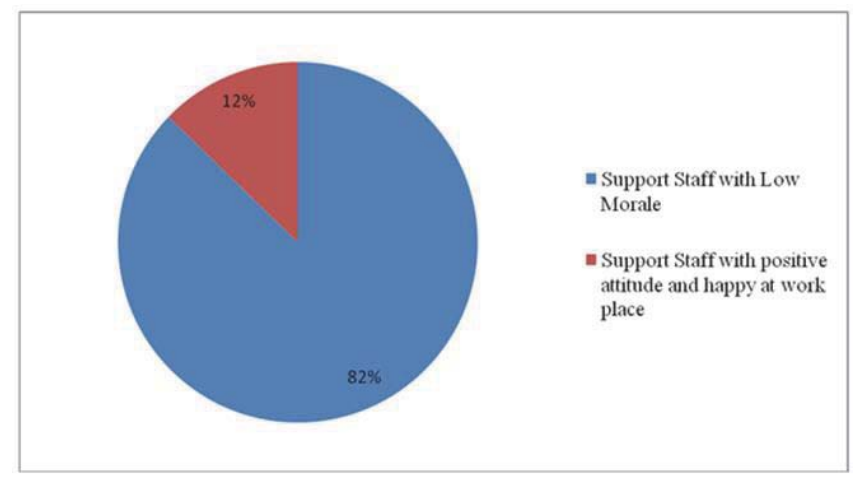

Figure 4.7: Support Staff response on their Morale at work $(n=150)$

Some (35\%) agreed that threats from head teachers were used to make the support staff work whenever they were seen being reluctant to work. Most (65\%) head teachers however denied that the use of threats existed in their schools. Those who identified existence of threats were quick to note that threats were making support staff not to perform their duties willingly. They maintained that such workers were not productive in the absence of the head teachers.

Most (93\%) support staff was feeling threatened by their head teachers and some were working under duress. They maintained that it was hard for support staff to work well because of fear of being quarreled when they fail to satisfy the demands of head teachers. The support staff however maintained that little work was being done in the absence of the school administration. Support staff also noted poor workmanship as they were not working to meet the institutional goals or towards attaining job satisfaction. The head teachers needs to recognize that motivation of support staff influence their performance at various levels. When their motivation level is low, their performance declines and when their morale is high, their ability to perform is high (Deci, 2001).

\subsection{Effects of Working Conditions of the Support Staff on their Performance in Public Secondary Schools}

The second objective was to establish the effects of the working conditions of the support staff on their performance in public secondary schools in Rarieda Sub-County? The research question responded to was: How do the working conditions of the support staff affect their performance in Secondary schools in Rarieda Sub-County. The respondents were asked to rate the effects of working conditions on their performance in order of their magnitude, their responses were presented in Table 4.6 .

Table 4.6: Effects of Working Conditions on Performance as indicated by Head Teachers ( $n=31)$, Support Staff $(n=150)$

\begin{tabular}{ccccc}
\hline \multirow{2}{*}{ Effect of Working Conditions on Performance } & \multicolumn{3}{c}{ Head teachers } & \multicolumn{2}{c}{ Support Staff } \\
& $\mathbf{f}$ & $\mathbf{\%}$ & $\mathbf{f}$ & $\%$ \\
\hline Low moral & 30 & 97 & 150 & 100 \\
Inefficiency & 28 & 90 & 136 & 91 \\
Low productivity & 25 & 81 & 135 & 90 \\
Job dissatisfaction & 25 & 81 & 130 & 86 \\
High rate of employee turnover & 20 & 65 & 120 & 80 \\
\hline
\end{tabular}

From Table 4.6, the study established that working conditions do affect work performance in several ways. The fact that 
working conditions leads to Low moral among support staff was noted as a major effect as was indicated by most (97\%) head teachers and by all (100\%) support staff. The study also established that poor working conditions highly lead to inefficiency among support staff as was noted by most (90\%) head teachers and most (91\%) support staff.

Low productivity was also noted to be brought by poor working conditions as was established from some (81\%) head teachers and most (90\%) support staff. The study equally established that poor working conditions lead to Job dissatisfaction as was indicated by some (81\%) head teachers and by most (86\%) support staff. Finally the study established that poor working conditions do lead to high rate of employee turnover as was reported by some (65\%) head teachers and some (80\%) support staff.

During interviews with head teachers, the study established that working conditions of support staff in secondary schools were having great effects on the performance of support staff. Most (95\%) head teachers acknowledged that support staff in secondary schools were having low morale for work. They argued that when the conditions were not conducive working conditions was necessary to boost the morale of the support staff in secondary schools. The findings also concur with that of Kahya (2007) that there were substantial relationship between employee performance, both job grade and environmental conditions. Poor work place conditions result in decreasing employee performance

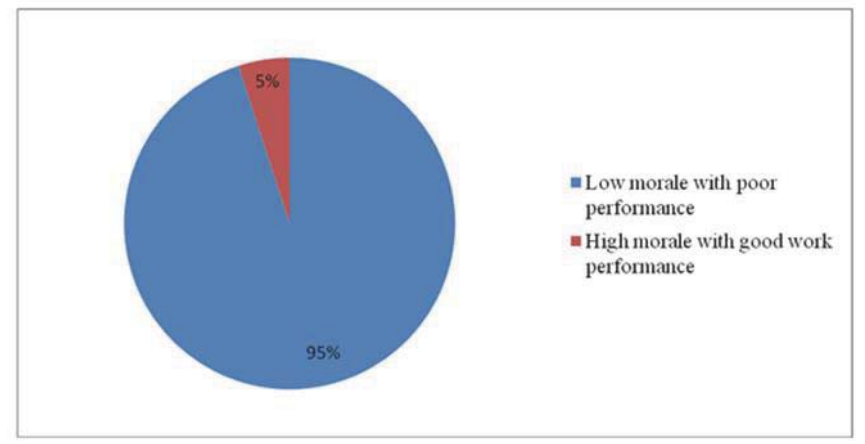

Figure 4.8: Principal's Response on the Support Staff Morale in schools $(n=31)$

All (100\%) support staff noted that they were not working with enthusiasm they ought to have at work place, this they mentioned was due to the harsh working environment as Leblebici (2009) also observed that the quality of environment in work place determines the level of employees' motivation, subsequent performance and productivity. Most (79\%) support staff further explained that their low morale was making their work to be poor and that most of them were working because they had no other place to turn to. The study also established from the support staff that delivery of good services depends on good treatment of the staff. The findings are in line with those of Leblebici (2009) that the quality of environment in work place determines the level of employees' motivation, subsequent performance and productivity.

The study also established during interviews that there was a lot of inefficiency among the workers as a result of working conditions prevailing among the support staff. The head teachers who participated in the study unanimously agreed that the support staff in secondary schools were not very efficient compared to those in private sector. Most (88\%) head teachers felt that it was due to negligence among the support staff, and that once they had gotten employed they became complaisant and neglect their duties.

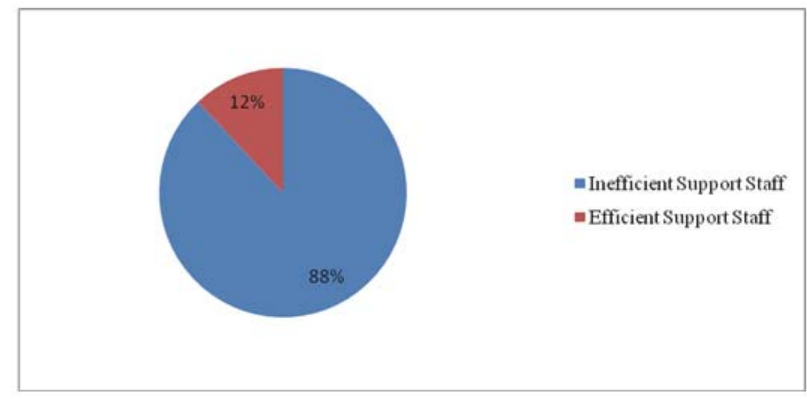

Figure 4.9: Principal's Response on Work Efficiency among Support Staff in schools $(n=31)$ 
According to all (100\%) support staff who participated on the study, their working environment dictated their way of seriousness as Kahya (2007) maintained that there is a substantial relationship between employee performance both job grade and environmental conditions and that poor work place conditions results in decreasing employee performance. They maintained that they were working under harsh conditions from the hands of the principals that made them not to perform their work well as every time they were tensed and no employee was ready to take an action unless informed to do so by the head teachers or other teachers.

Some also maintained that they were being made to work longer hours after normal working hours and that made some of them to be inefficient at certain periods of the day. The findings are also in congruent with those of Ademokoya (2006) that poor working conditions such as delay in promotion and salary payment and unattractive office accommodation have significant adverse influence on working performance of both teachers and interpreters. Hours expected to work, annual wage, and job insecurity play a vital role in the association between health- and work- related performance for both work attendance and self reported work performance.

The study further established that there was low productivity among the support staff in secondary schools. This was due to lack of proper working tools according to most (76\%) support staff. They also explained that the head teachers were reluctant to provide them with necessary tools like computers, lawnmowers, and gumboots among others to enable them improve their productivity. This finding concurs with Republic of Kenya (2006) recommendations that public universities should strategize on how to improve the working conditions of support staff through provision of the necessary infrastructure such as computers, office space and furniture.

Some (43\%) support staff noted that working long hours and walking long distance to and from work also was contributing to low productivity among the support staff. They also argued that lack of job description also was contributing to the low productivity among the support staff.

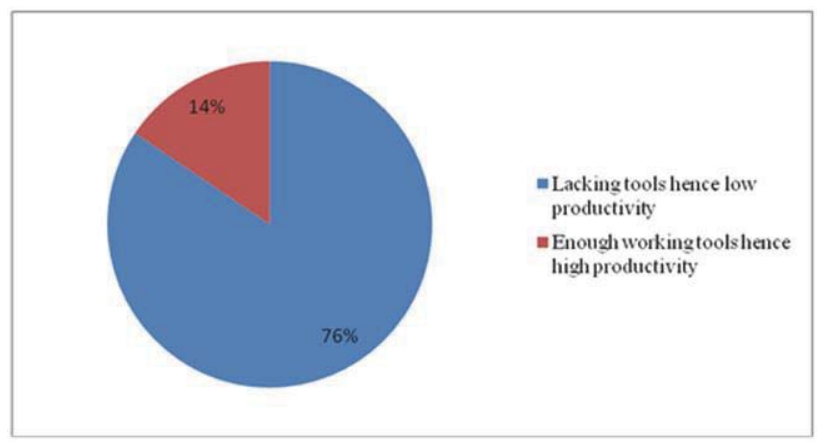

Figure 4.10: Support Staff response on the Effects of Working Tools on Job performance $(n=150)$

According to most (71\%) head teachers, low production among the support staff was due to lack of personal commitment among the support staff. They further argued that some support staff committed to work were doing their work well and faster unlike some who would want to be pushed to do their own job. The head teachers expressed disappointment that the low productivity was being realized from the support staff who were coming from the locality of the school.

The study established that the working conditions in the schools were leading to job dissatisfaction among the support staff. According to all (100\%) head teachers, most support staffs were expressing dissatisfaction with their job because they could not follow simple instructions. According to all (100\%) head teachers the uncooperative workers were the ones expressing dissatisfaction. On their part dissatisfaction was being necessitated by the way the employee were being listened to, being treated and given free room to perform his/her duties. According to support staff the way an employee's feelings and contributions were considered would lead to job satisfaction or not.

The study established that there was high rate of employee turnover among the support staff in secondary schools by following the duration each support staff had taken since their date of appointments. According to most (83\%) head teachers this was being attributed to some going for further studies while others were due to natural attrition which is either retirement or passing on. The head teachers also attributed the turnover rate of support staff to lack of commitment among the workers that usually leads to being laid off. This finding concurs with the observation by Odebero (2010) that workers appreciate professional careers that allows them to grow. As such they tend to move from jobs where they perceive no growth. 


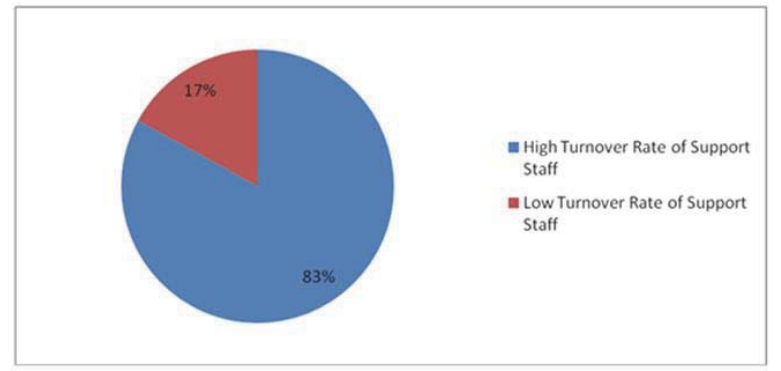

Figure 4.11: Principal's Response on the Support Staff Turnover rate $(n=31)$

According to all support staff, the high turnover rate was due to poor working environment to which support staffs were subjected to. They also maintained that support staffs were not being offered job security and any slight difference with head teacher would warrant them sacking. The study further established that the high turnover rate was because most of the support staff were employed in schools on temporary basis or on casual employment and were not having letters of appointment, as such could be sacked at will by the head teacher.

\subsection{Challenges Faced by Support Staff in their Work}

The first objective was to determine the challenges faced by support staff in Rarieda Sub-County public secondary schools. The research question responded to was: What are the challenges faced by support staff in secondary schools in Rarieda Sub- County. The respondents were asked to rate the challenges they were facing at work place in order of their magnitude, their responses were as shown in Table 4.7.

Table 4.7. Challenges faced by support staff in their duties as indicated by support staff as indicated by Head Teachers $(n=31)$ and Support Staff $(n=150)$

\begin{tabular}{ccccc}
\hline Challenges faced by support staff & Head Teachers & \multicolumn{3}{c}{ Support Staff } \\
& f & $\%$ & f & $\%$ \\
\hline Inadequate working tools & 28 & 90 & 150 & 100 \\
Working past official hours/ no overtime & 27 & 87 & 150 & 100 \\
Low salary & 26 & 84 & 150 & 100 \\
Doing undesignated duties & 23 & 74 & 135 & 90 \\
Too much work load & 17 & 55 & 132 & 88 \\
Interference from local community & 15 & 48 & 130 & 87 \\
Lack of housing & 15 & 48 & 128 & 85 \\
Delayed salary & 13 & 42 & 126 & 84 \\
Yearly increment not paid & 11 & 35 & 120 & 80 \\
No pay for extra work & 10 & 32 & 118 & 79 \\
Not being given imprest even when in financial need & 09 & 29 & 110 & 73 \\
\hline
\end{tabular}

From Table 4.7, the study established that support staff is faced with the major challenge of inadequacy of working tools as it was reported by $90 \%$ of head teachers and all $100 \%$ support staff. Working past official hours/ no overtime was also established as a major challenge as was reported by most (87\%) head teachers and all (100\%) support staff. Low salary was equally reported by most (84\%) head teachers and all (100\%) support staff. Doing undesignated duties was also reported as a major challenge by most (74\%) and most (90\%) support staff. Some (55\%) head teachers and most (88\%) support staff also reported too much work load as some of the major challenge to their duties.

From Table 4.7 the study further established that according to head teachers Interference from local community was a minor challenge to the work performance of the support staff as only (48\%) noted the challenge while to support staff it was a major challenge as (87\%) identified that it was a problem. Lack of housing was also seen by head teachers as a major challenge to the support staff work performance since only (48\%) head teachers identified the problem, on the other hand it was a major problem according to most (85\%) support staff.

The study also established among the support staff that delayed salary was a major problem as noted by most (84\%) support staff, but to head teachers, it was a minor challenge as only (42\%) head teachers considered it as a 
challenge. Most (80\%) support staff equally noted yearly increment not paid as a major problem while only a few (35\%) head teachers noted it as a challenge. Most (79\%) support staff indicated no pay for extra work as a major problem, while only (32\%) maintained that it was a problem. Not being given imprest even when in financial need was indicated by most (73\%) support staff, while head teachers did not see it as a problem as only a few (29\%) noted it a challenge to the work performance of support staff.

During interviews the study established that support staff were faced with very many challenges that needed to be addressed in order to enable them perform their role in the schools perfectly. Inadequate working tools were reported by most (67\%) head teachers who maintained that this was due to poor storage. The head teachers however maintained that their schools do buy enough working tools which were being stolen by the support staff who were suppose to be using them. Some (67\%) further blamed the support staff for being careless in handling the tools and machines given to them after such machines were broken down then they blamed the administration for not buying them working tools. The head teachers cited cases of the secretaries whom they blamed for not handling computers well making them to breakdown every now and again.

On their part, the support staff during interviews all (100\%) support staff maintained that they were forced to work with outdated tools like type writers and duplicating machines instead of computers and printers. The grounds men were made to use slashers instead of lawnmowers. This they noted was making their work difficult as they were forced to take longer time doing what they would have completed in shorter period. Some (78\%) support staff also blamed the head teachers for not being ready to repair their machines in time and instead forcing them to use the broken down machines claiming that the schools were not having money and that the machines could still serve despite the broken parts. This finding concurs with the Republic of Kenya (2006) survey report which maintained that lack of working tools was affecting support staff work performance and recommended that public universities should strategize on how to improve the working conditions of support staff through provision of the necessary infrastructure such as computers, office space and furniture.

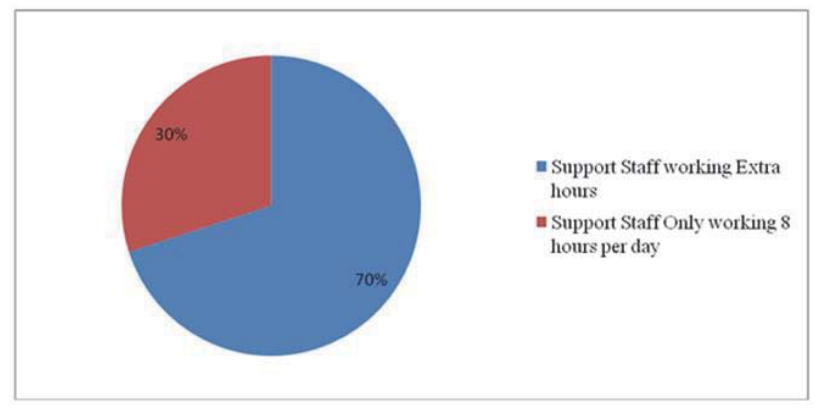

Figure 4.12: Principal's Response on the Extra working Hours by Support Staff $(n=31)$

The study also established during interviews that the support staffs were working past official hours. All (70\%) head teachers attributed this to lack of enough personnel as schools had no money to employ more people. The head teachers further maintained that the extra hours were not paid for or compensated because the school was not a profit making organization and that anybody working in a school was suppose to volunteer as they were helping the young people to come up. The head teachers further blamed the support staff for being laxed most of the office hours which caused them to work past official hours.

All (100\%) support staff attributed working longer hours to lack of organization by the school administration. They further noted that despite working for longer hours they were being summoned by the administration whenever they were late not considering the extra hours they were serving the school. Some (78\%) support staff noted that their schools had clock in-clock out record book which was only taken serious on the part of clock in but their head teachers were quiet over the hours of clock out as long as it was past the working hours. This situation they noted was demoralizing to the support staff as they felt being over exploited without appreciation.

The other challenge established by the study was low salaries given to support staff. This was noted to be lowering the morale of support staff by some (56\%) head teachers. The head teachers however attributed this to the less amount located by the government towards personal emolument vote head. Some (74\%) head teachers also noted that most support staffs who were complaining were either semi skilled or untrained and were falling in the lowest cadre of the government scale job group. These head teachers therefore confirmed that the support staff deserved the salary scale 
they were earning and had no grounds for complaining.

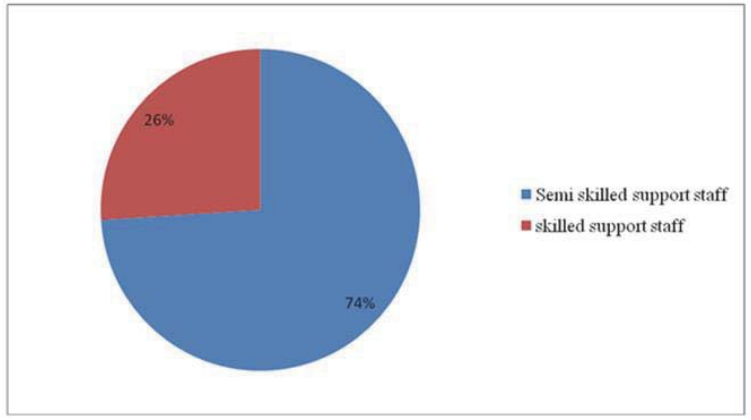

Figure 4.13: Principal's Response on the Low pay to Support Staff $(n=31)$

All (100\%) support staffs during interviews were not satisfied with the salaries they were earning. They argued that their counterparts in the parastatals and private sectors were earning higher than them yet they are expected to do similar jobs. Some (67\%) support staff felt that they were trained and were entitled to earn higher than they were earning, this they noted was lowering their moral for hard work. They also noted that their salaries were always deducted when clock in records were checked for the number of days they failed to report on duty despite the fact that they gave genuine reasons for their absence. These findings of the study are also similar to that of Mureithi (2011) who reported that the non-teaching staff had been ignored and were grossly under paid.

Support staffs were also faced with the challenge of doing undesignated duties which were never paid. They also maintained that despite the extra duties they were always quarreled by the administration whenever they delay on doing their routine duties. Some of them were not happy at work place as they were being tossed left and right by their bosses starting from the head teachers, deputy head teachers, bursars and other teachers. This was making support staff feel frustrated as they were to obey all of them and each was giving them extra duties.

Too much workload was established by the study to be another challenge facing support staff. All (80\%) head teachers, attributed this to challenge to the few number of support staff stipulated by ministry to be employed per the number of students a school has. As much as the head teachers acknowledged that it was leading to poor work performance, they maintained that they had no otherwise but had to go by the government policy. Some head teachers also attributed too much workload to work back log carried forward by the support staff due to laxity from doing the right thing at the right time. This finding concurs with the report by the Republic of Kenya (2011) that the rapid increase in student numbers has not been commensurate with staff numbers, making the support staff take additional loads every successive year.

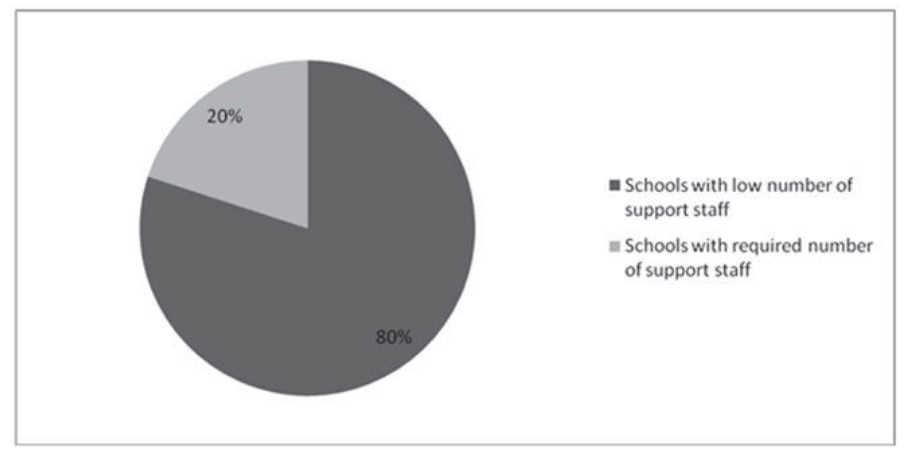

Figure 4.14: Principal's Response on the Low number of Financial Support Staff $(n=31)$

Most (86\%) support staff felt that their services were not recognized as they had too much work to do and they kept on piling as the year progresses. This they say was making them to lose interest in their job as nobody was appreciating the work they were doing but only blaming them for the undone work. Another (56\%) support staff blamed the school administration for piling work in their offices and when they were released, they were given deadline to complete them. 
The support staff further blamed the school administration for not allocating them duties in good time, such they say was making most of them sick, confused on where to start and when they delay, they were receiving memos of disciplinary action. Such kind of situation was interfering with the work performance of the support staff.

Interference from local community was also established as another challenge to the work performance of the support staff. Some (74\%) head teachers noted the interference to the fact that support staff were from within their locality as such they had personal problem. They were however quick to admit that some support staff from other communities were being affected due to nepotism. Some support staff, they maintained were generally scared without any cause or interference and were raising alarm for no reasons.

Some (67\%) support staff noted that their efforts to serve the schools were being jeopardized by the interference from the local communities. They cited the cases of school watchmen who were being harassed by the local community at night while on duty. They equally cited the cases of bursars who were being harassed for being too strict on fee payment issues. Such kind of interference was noted by support staff to be affecting their work performance and lower their morale to perform their duties diligently. This study finding can be supported by the Republic of Kenya (2006) report contended that members of support staff in public universities have over the years served under difficult circumstances such as political interferences, poor remuneration and challenging working conditions. The report adds that the rapid increase in student numbers has not been commensurate with staff numbers, making the support staff take additional loads every successive year.

Most support staffs were not housed by the schools where they were working and this made them to be demoralized as was pointed by most (85\%) head teachers. They further maintained that support staffs were the first people in the school compound as some arrive as early as 4. am and leave as late as 10pm. These support staffs were finding it difficult to perform their duties well for being away from their houses and being tired after travelling to workplace the head teachers maintained. The head teachers attributed lack of housing in schools to poor priority of the Board of Management in schools.

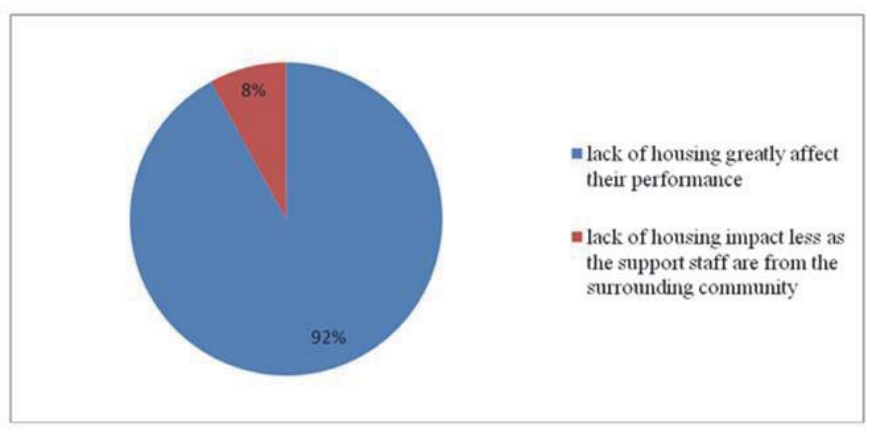

Figure 4.15: Support Staffs' response on the Effects of the housing facilities $(n=150)$

Most (92\%) support staff noted that lack of housing was affecting their work performance as they were expected to be in schools before the students and the teachers. They further noted that their security was not ensured as such they were not relaxed even when at work especially during odd hours. Some (45\%) support staff were not happy that they were not being given risk allowances as much as they were risking their lives to their work place. Most support staff were not happy with their institutions because they were not housed while teachers were being housed yet teachers relied on them. Delayed salary was also a challenge noted by some (56\%) head teachers. The head teachers noted that when the government allocation to schools was delayed, the salaries of support staff were also being delayed and this was making the staff to slow their working pace. The support staff also do see the school administration as not willing to pay their salaries as such the delayence do bring conflict between the staff and administration which in turn was affecting work performance of the support staff.

According to most (87\%) support staff, salary delay was making them to look for alternatives to survival for their families which in turn means slowing the pace of their work performance. Delayence in salary was also seen by support staff as lack of recognition of their contributions to the schools as the head teachers could borrow money from other vote heads to pay their salaries. They also maintained that most of the support staff were not being paid during the third term of the year and were only being given lamp sum at the beginning of first term. During which period they were expected to survive without pay and this affecting their work performance. This study finding concurs with that of the report by 
Republic of Kenya (2011) revealed that salaries have remained low for a long time and at times salaries delay by one or two months. This has impacted negatively on the performance of the support staff in the civil service.

Non payment of yearly increment was another challenge that was affecting the work performance of the support staff. Most (77\%) support staff pointed out during interviews that their salaries had not been increased for the past two years as their head teachers were pointing out that the money being sent by the government was only taking into account the number of support staff who were supposed to be in school but not increase in their salaries. The study also established that most (75\%) support staffs were stagnant on the same salary scale and this was lowering their work performance.

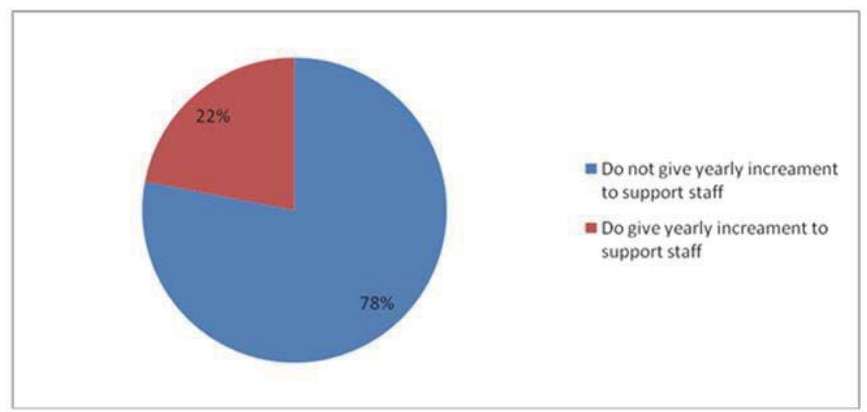

Figure 4.16: Principal's Response on the Support Staff Yearly Increment $(n=31)$

According to most $(78 \%)$ head teachers, on payment of yearly increment was not their own making as the government money being sent to schools were having its allocation and does not give room for virement from other vote heads. The head teachers however acknowledged that work performance of the workers was being affected when their salary was not increased. Some (66\%) head teachers noted that support staffs were always on go slow whenever their salaries were not increased.

The study established that non-payment of extra work done was affecting support staffs' work performance. This was noted by all (100\%) support staff during interviews. They pointed out that teachers were always paid for extra lessons or during remedial but to them the schools had no provisions for such pay. This they maintained was making most support staff to resist doing extra work or were doing them carelessly. Support staffs also were feeling that schools do not value their roles in the operations of the schools as such they were in most cases reluctant to take up some of their responsibilities. This kind of treatment was bringing ill feelings among the support staff as they were also using skills and energy like teachers to enable the schools run. According to some (32\%) head teachers, support staff were not being paid for extra work because they were always relieved during the holidays when schools closes yet they are paid for the duration. The head teachers however maintained that the support staffs were always given some token though they want equivalent of what teachers were getting.

The study established that support staffs were not being given imprest even when in financial need. According to all (100\%) head teachers, it was a directive from the ministry of education that schools were not to give imprest not only to support staff but also to teachers. The head teachers however maintained that they were occasionally on trust do give some amount to the workers whenever they had financial problems. The head teachers also pointed out that they were not giving such monies to those who had failed to refund them as was agreed earlier.On their part most (81\%) support staff noted that they were not able to carry on with their duties whenever they had problems and their schools were not ready to give them financial support. They also pointed out that they had no other place which could trust them more than their employers yet when turned down, they had to stop working as they think of alternatives.

The study findings in this section were similar to those of Briar (2010) that support staff face a number of challenges such as low pay, are demoralized by the public and politicians who assume that their skills and values are of little meaning, lack of training opportunities, receive less sick leave than teachers although they are exposed to similar health risks at work, not sure of pay progression, lack of job security and description and not being paid during school holidays. The study finding in this section also concurred with the results of the study by Research Division in New Zealand (2011) that support staff face challenges such as work load issues- including too many competing demands which interfered with their ability to effectively complete tasks, lack of time to tackle the amount of work and /or insufficient back up. Their ideas not being sought or listened to, insufficient training /professional development, irregular/inadequate support, lack of induction and being left outside the communication networks in the school. 


\subsection{Strategies used by Support Staff to Cope with Challenges Faced in their Duties}

The fourth objective was to; Assess how support staff cope with the challenges they face in public Secondary Schools in Rarieda Sub-County. The research question responded to was: How does support staff cope with the challenges they face in Secondary Schools. The respondents were asked to rate the contributions of the stakeholders to quality leadership, their responses were as shown in Table 4.8.

Table 4.8. Strategies used by support staff to Cope with the Challenges as indicated by Head teachers $(n=31)$ and support staff $(n=150)$

\begin{tabular}{ccccc}
\hline \multirow{2}{*}{ Strategies used by support staff } & Head Teachers & \multicolumn{2}{c}{ Support Staff } \\
& $\mathbf{f}$ & $\%$ & $\mathbf{f}$ & $\%$ \\
\hline Working extra hours & 31 & 100 & 150 & 100 \\
Engage in small businesses & 31 & 100 & 150 & 100 \\
Staying in the Village & 31 & 100 & 138 & 92 \\
Rent house at market & 30 & 97 & 135 & 90 \\
Procure loans & 29 & 93 & 132 & 88 \\
Engage in manual works after work & 24 & 77 & 126 & 84 \\
Waking up earlier & 23 & 74 & 123 & 82 \\
Bicycles for going to work & 20 & 65 & 118 & 78 \\
Working in shift & 18 & 58 & 100 & 67 \\
Carry tools from home & 9 & 29 & 67 & 45 \\
\hline
\end{tabular}

Working extra hours as a coping strategy was widely used as was established from all (100\%) head teachers and all $(100 \%)$ support staff who filled the questionnaires. Support staffs also engage in small businesses as was established from all (100\%) head teachers and all (100\%) support staff. Support staffs also do stay in the Village as a coping strategy as was reported by (100\%) head teachers and most (92\%) support staff. Renting house at market as a coping strategy employed by support staff was mentioned by (97\%) head teachers and (90\%) support staff.

Table 4.8 also reveals that support staff does procure loans as a coping strategy as established from (93\%) head teachers and (88\%) support staff. Engage in manual works after work was also mentioned by (77\%) head teachers and (84\%) support staff. The study equally established that support staff do Wake up earlier to start work earlier as mentioned by $(74 \%)$ head teachers and by some (82\%) support staff. Using bicycles for going to work as a coping strategy was established by the study from (65\%) head teachers and from (78\%) support staff. The study also established that support staff were working in shift as was indicated by some (58\%) head teachers and (67\%) support staff. Carrying of tools from home was also mentioned by some (29\%) and (45\%) support staff respectively.

During interviews all (100\%) head teachers acknowledged that support staffs were working extra hours to help cope with too much work load. The head teachers also maintained that support staffs were working extra hours only when there was too much work backlog and this was only for a short period that does not warrant compensation. Some (64\%) head teachers also maintained that they were giving support staff some days off whenever they work for extra hours. However they maintained that support staffs were never interested on the off days but wanted financial gains.

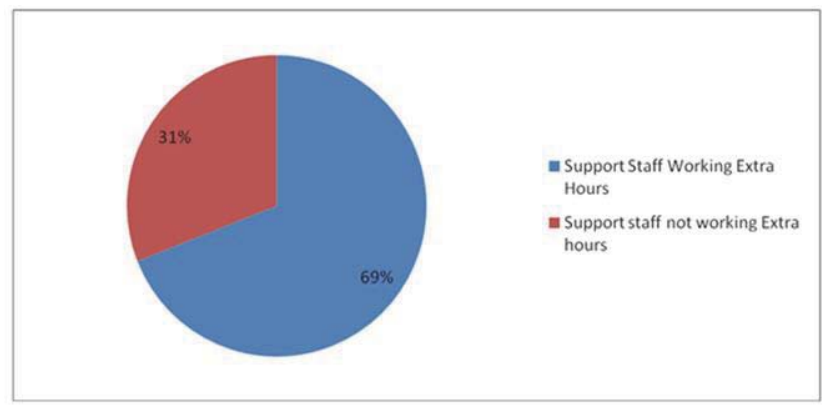

Figure 4.17: Support Staffs' Response on Working extra hours $(n=150)$

On their part, all (100\%) support staff pointed that they were made to work extra hours which were never compensated as 
the head teachers were citing lack of finances. This the support staff noted was leading to low morale and low work performance. Most (69\%) support staff maintained that they were always being made to work extra hours forcefully by their schools' administration as none of them were willing to do extra job. They added that their morale was low as much as they were seen to be using the extra work as a coping strategy. Some (37\%) support staff blamed inefficiency at work place due to forceful overtime. This they noted was making them more tired before the following day's work.

The fact that some support staff engage in small businesses was pointed out by all $(100 \%)$ head teachers who noted that this was a way of coping with low salaries. The head teachers also noted that they were however cautioning the support staff not to neglect their duties as they were conducting their business after work. Some (25\%) head teachers revealed that they advanced soft loans to their support staff so as to open small businesses.

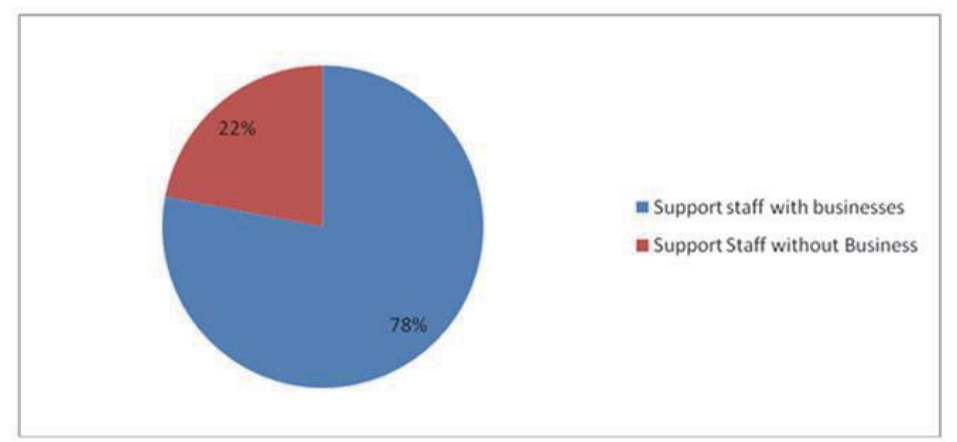

Figure 4.18: Principal's Response on Advancing loans to Support Staff to start business ( $n=31$ )

Most (78\%) support staff also mentioned during interviews that they were running small scale businesses to help subsidize the low salary they were earning. They further pointed that their businesses were helping them to solve their financial problems whenever there were delayence of salaries. They also maintained that their businesses were saving them the problem of going for imprest from their head teachers. This coping strategy was also helping them to settle on their jobs and do improve their work performance.

The study also established during interviews that support staffs were staying in the village. All (100\%) head teachers pointed that majority of the support staffs in schools were from the schools' neighboring communities. This they noted was saving on the transport cost as support staff come to work. This was also helping schools not to build houses for support staff. Most head teachers also noted that this was helping to bring good relations between secondary schools and the surrounding communities.

Most (79\%) support staff were in agreement that their stay in the village was helping them not to pay rent, reduced transport cost and also helped them to be at their work station at the right time. Most (87\%) support staff maintained that they were coming from the communities around the schools as such staying in the village was also a coping strategy for support staff in addressing the challenge of inadequate housing. Most schools in the district lack funds to put up houses for support staff. Most (76\%) head teachers also pointed that some of support staff in their schools were renting houses at market near the school compound. They also attributed this as a way of coping with inadequate staff houses in secondary schools. The head teachers were however quick to note that most of those who rented houses were from other communities or were coming from regions far from their working stations.

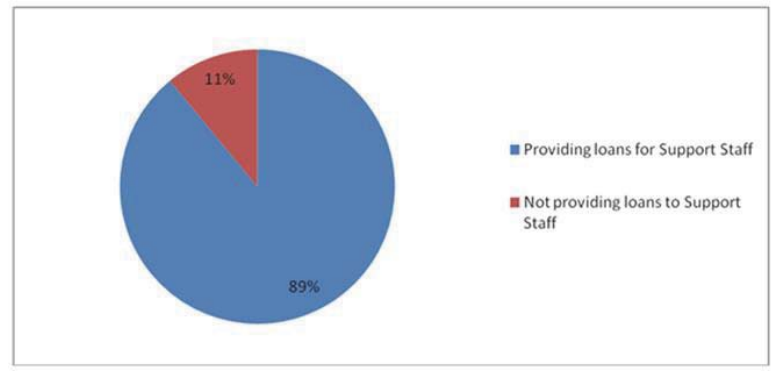

Figure 4.19: Principal's Response on Loans $(n=31)$ 
According to most (89\%) head teachers, support staffs were taking loans from the schools and banks to help them cope with poor remuneration and delay in salaries from the government. The head teachers also noted that support staffs were trying to improve their financial statuses which in turn were helping to improve work performance. Most (69\%) support staff were in support with the views of head teachers that loans were enabling them to solve their financial problems and were making them to work without stress.

Most support staffs were engaging in manual work after official working hours was established by the study from some (67\%) head teachers. They further noted that this was also meant to help solve the challenge of low salaries earned by support staff. The head teachers also maintained that financial stability was making the support staff to improve their work performance. Most (89\%) support staff agreed that they were engaged in manual work after official working hours. This they noted was making them to be economically stable, hence improved work performance. They however pointed out that this strategy was making them tired as they were already exhausted after working for the official eight hours.

Waking up earlier was established during interviews with head teachers to be another coping strategy employed by support staff. All (100\%) head teachers noted that support staff were waking up early to cope with the heavy workload that are existing due to lack of enough personnel among support staff in secondary schools. The head teachers also maintained that the duties of support staff required that they work longer hours to enable the schools run their activities smoothly during the day. According to most (69\%) support staff, they were waking up earlier because they were having too much workload during the day. They also pointed out that they were using the coping strategy to improve their work performance as starting to work earlier do enable them to do a lot of work during the day.

Using bicycles for going to work was established by the study to help solve the problem of lack of commuter allowances as was explained by some (37\%) head teachers. The head teachers also noted that using bicycles helped support staff to be efficient as it was making them reach their work place in time and when not exhausted. The head teachers further explained that this coping strategy was also helping the schools to solve the problems of lack of housing for support staff.

According to some (54\%) support staff, the strategy of using bicycle was introduced by support staffs to enable them reach their working stations in time and to enable them go back home faster after work. Some (34\%) support staff also explained that using bicycle was helping them to solve the challenge of lack of commuter allowances. Some (25\%) support staff also explained that using bicycle helped in solving the challenge of working past normal working hours during which other means could not be found.

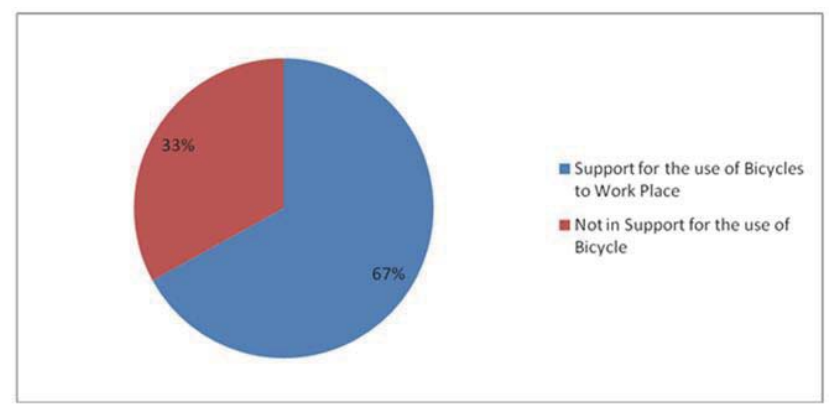

Figure 4.20: Head teachers' Response on use of Bicycle by Support Staff $(n=31)$

Most (67\%) head teachers also agreed with the sentiments of support staff that using bicycle was helping to solve various challenges which support staff were facing at their working place. They further revealed that bicycle helped to reduce lateness among most support staff they were reporting on time and were able to be more efficient at work. The head teachers also got relieved of the need for commuter allowances which they were demanding when they were using other means for coming to their workplace.

Working in shift was established during interviews with all (100\%) head teachers to be existing among the support staff who were performing essential duties that required 24 hour services. The head teachers also noted that the shift system was also used where workers were fewer than the number required. Some (45\%) head teachers also noted that working on shifts was making the support staff not to feel tired and be inefficient. According to all (100\%) support staff, working on shift was meant to help solving too much work load and working for longer hours. They also noted that working on shift was helping to solve the challenge of working past normal working hours. 


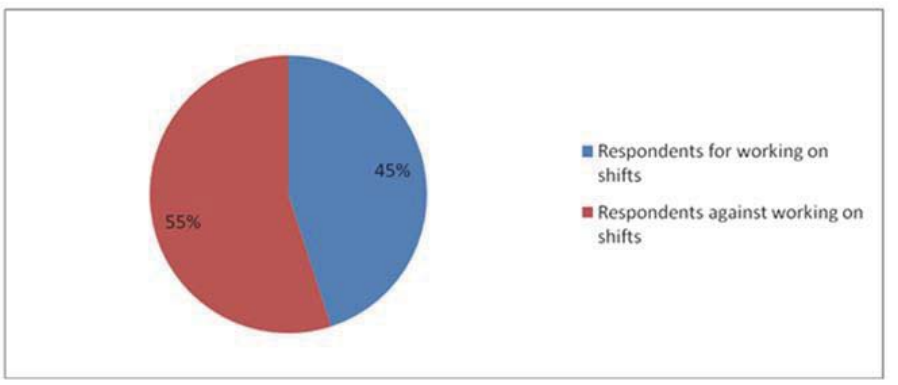

Figure 4.21: Principal's Response on the Effects of Support Staff working on shifts $(n=31)$

Carrying tools from home was established from some (35\%) head teachers that it was helping to solve the challenge of lack of working tools. They added that support staffs were only coming with tools occasionally when there was need but not that they were bringing tools constantly for their routine duties. According to some (23\%) support staff, they were bringing tools as their schools were not keen in purchasing the tools they needed to perform their duties. Support staff also added that their school administrations were not bothered on how they were going to get tools once they were assigned duties.

\section{Summary, Conclusions and Recommendations}

The study established that support staff in Rarieda Sub-County work under very poor conditions such as inadequate working tools, low salary and low motivation.

The study established that working conditions affect work performance of support staff mentioned by $100 \%$ of the head teachers and support staff. That is good working conditions leads to better performance and poor working conditions leads to low work performance.

Based on the findings of the study the following conclusions were made.

i. Support staff in Rarieda Sub-County work under very poor conditions such as lack of training, inadequate working tools, low salary and low motivation.

ii. Working conditions affect work performance of support staff.

iii. The main challenges faced by support staffs were low salaries, inadequate working tools, being over-worked, late payment of salaries, lack of housing and walking long distance to school

iv. The main coping strategies for support staffs were: engaging in small scale businesses; carrying tools from home, renting houses at nearby market centers and taking loans.

Based on the findings and the conclusions of the study, the following recommendations were made:

i. Increase the salaries of support staffs.

ii. Principals should avail adequate working tools such as gumboots, torches, rain coats, utensils and equipment.

iii. Schools should recruit more support staffs to address the challenge of the high pupil-worker ratio.

iv. Schools should put up houses for support staffs.

v. Principals should improve the working conditions of support staffs to enable them perform their work more effectively and efficiently.

vi. Ministry of Education should take full payment of the support staff.

vii. Recruit more support staffs to address the challenge of the high pupil-worker ratio.

viii. M.O.E should design relevant in-service courses for support staffs and head teachers to minimize challenges faced.

\section{References}

Ademokoya, A.J. (2006).Influence of working conditions on performance of sign language interpreters and teachers of deaf students in Oyo, state Nigeria. African journal for the psychological study of Social Issues Vol.9 (2) 233-248.

Alvares, B. Gillies, J., \& Biadsher, M. (2003).Beyond Basic Education; Secondary Education in the Developing World. Washington D.C. The World Bank.

Bakhda, S. (2004).Management and Evaluation of Schools. Nairobi: OUP.

Beason, C., Kerry, C., \& Kerry, T. (2003).The Role of Classroom Assistants. Birmingham: National Primary Trust.

Blatchford, P., Bassett, P., \& Brown, P. (2006).Deployment and Impact of Support Staff in Schools. Report on findings from the Second National Questionnaire Survey of Schools, Support Staff and Teachers. Webster Institute of Education, University of London. 
Blatchford, P., Bassett, P., Brown, P. (2008).Deployment and Impact of Support Staff in schools Characteristics, Working Conditions and Job Satisfaction of Support Staff in Schools. Webster Institute of Education, University of London.

Briar, (2010).Valuing the work of support staff. London: OUP. D.E.O, (2012).Rarieda Sub-County Education Office.

Deci, P., Edward, L., Richard, R., \& Ryan, R.M. (2001). Need Satisfaction, Motivation and Well-being in the Work Organizations of a Former Eastern Bloc County: A Cross Cultural Study of Self-determination, Personality and Social Psychology. Bulletin, Vol. 27,930-942.

Fraenkel, J.R., \& Wallen, N.E. (2009).How to Design and Evaluate Research in Education, (7th Edition). Boston: McGraw- Hill.

Gillian, C. (1982). Qualitative Research in Psychology: Expanding Perspectives in Methodology and Design. Cambridge: Harvard University Press

Higlis, C. (2008).Planning for Cultural Diversity. Paris; UNESCO International Institute For Educational Planning.

Holden, J. (2006).Work performance decrements associated with Australian working conditions. Journal of Business and Psychological Vol. 14(3) 481-487.)

Jabuya, A. M., Tirop, L. (2011). Influence of motivation of teachers performance in secondary schools for vision 2030 in Uriri District. Proceedings of the national workshop for the Educational Management Society of Kenya held at Nairobi University.

Kahya, E. (2007). The effects of job characteristics and working conditions on job performance. Available on line 26 March 2007.

Kerry, T. (2005).Towards a Typology for Conceptualizing the Roles of Teacher Assistants. Educational Review 57 (3), pp. 374-384.

KUDHEIHA (2010).Improving work conditions of members. Nairobi: KUDHEIHA.

Lavy, V. (2002b). Evaluating the effect of teacher group performance Incentives on students achievements. Journal of Political Economy, Vol. 110, pp. 1286-1318.

Lazear, E. (2002).Education in the 21st century New York; Hoover institution Press.

Leblebici, D. (2010).Impact of work place quality on employees productivity. Case study of a bank in Turkey.

Manda, D.K., Mwabo, G., \& Kimenyi, M.S. (2002).Human Capital Externalities and Returns to Education in Kenya Institutes for Public Policy Research and Analysis (KIPRA) Discussion PAPER No.13

Mbiti, D.M. (2003). Foundation of School Administration.Nairobi: OUP.

MOE (2010). Summative Evaluation of the Secondary School Curriculum.KIE.

Mugenda, O.M. \& Mugenda, A.G. (1999). Research Methods: Qualitative and Quantitative Approaches. Nairobi: Acts Press.

Mureithi, F. (2011).Non teaching staff deserves better houses. All Africa.com: Kenya: Non teaching staff deserves better houses. Retrieved from http://allarica.com/stories/201104211374.html on 10/20/2012 at 1.30p.m.

Mwikali, A, K. (2000). The relationship between financial incentives and employee motivations: A case study of the field officers of the Swedish Cooperative Centre Project in Kisumu District. A research project of Maseno University, Kenya.

Nakpodia, D.E. (2010). Human Resource Management in School Administration in Delta State Nigeria, Delta State University, Nigeria.Kamla-Raj Publishers.

New Zealand Research Division. (2011).Learning more about staffs in schools: results from surveys of principals and support staff members. Retrieved from http://www.educationcounts.govt.nz/publication/schooling/learning retrieved on 10/20/2012 at 11.21a.m.

Ngala, B.J.A. (2010). Motivation of teachers by Head teachers and its influence on Pupil Academic Achievement: A case study of Primary Schools in Eldoret, Kenya. Proceedings of the first national workshop for the Educational Management Society of Kenya held at Migori Teachers College.

Njeru, E.H.N., \& Orodho, J.A. (2003).Education Financing in Kenya Secondary School. Bursary Scheme. Implementation and challenges.Nairobi:IPAR No. 0358.4.

Nyongesa, M.J.B.(2007). Educational Organisation and Management.Nairobi:JKF.

Nyonje, O.R., \& Achieng, R.N. (2010).The influence of the entrepreneurs level of education and training on the performance of micro and small enterprises. Case of Kisumu city Bus Park. Proceedings of the first national workshop for the Educational Management Society of Kenya held at Migori Teachers College

Olayo, J. (2011). Employers to blame for workers' low output. Nairobi: East Africa Standard. P. 43. April 8.Standard Media Group

Orodho, A.J., \& Kombo, D.K.(2002). Research Methods.Nairobi: Kenyatta University, Institute of Open Learning.

Orodho, A.J.(2003).Essentials of educational and Social Sciences Research Method.Nairobi: Masola Publishers.

Republic of Kenya, (2011).Diploma in Education Management for Secondary schools. Nairobi: KLB.

Republic of Kenya (1999). Totally Integrated Quality Education and Training .Report of The Commission of Inquiry into the education system of Kenya Nairobi: Government Printer.

Republic of Kenya.(2001).Public service ethics in Africa. New York: Vol.1

Republic of Kenya.(2006). Transformation of Higher Education in Kenya. Report of the Public Universities Inspection Board. Nairobi: Government Printer.

Republic of Kenya. (2007). Guidelines for the Implementation of Free Secondary Education. Nairobi: Ministry of Education. P. 1. January 8.

Republic of Kenya.(2010).The Constitution of Kenya. Nairobi: Government Printer.

Sagimo, O.P. (2002). Management Dynamics. Towards Efficiency, Effectiveness, Competence and Productivity. Nairobi: EAEP.

Simatwa, E.M.W. (2010). Job satisfaction and dis- satisfaction among teachers in Kenya Proceedings of the first national workshop for the Educational Management Society of Kenya held at Migori Teachers College.

Thompson, R.(2002).Managing People.London:Heinemann.

Wichenje, K.M. (2011). Human resource challenges for head teachers in public secondary schools in Kakamega East District. Unpublished M.Ed thesis, Maseno University, Kenya.

Wohner, N. (2010). How to monitor employee performance. Retrieved from http://www.chow.com/how. on 10/20/2012 at 11.00a.m. 